\title{
Nieuw bewijsrecht, maar geen recht op bewijs?
}

\author{
Pieter Frans Lock*
}

Het bewijsrecht gaat op de schop. Op 31 mei 2018 is een wetsvoorstel tot aanpassing van het civiele bewijsrecht ter consultatie voorgelegd. ${ }^{1}$ Dit wetsvoorstel, dat grotendeels is gebaseerd op het advies van de expertgroep Modernisering burgerlijk bewijsrecht, ${ }^{2}$ bevat behartenswaardige uitgangspunten en innovatieve verbeteringen, maar soms ook aspecten die de wenkbrauwen doen fronsen. ${ }^{3}$ Een voorbeeld van een dergelijk aspect is het voorstel tot wijziging van art. 166 lid 1 Rv: het getuigenbewijsaanbod.

Het huidige art. 166 lid $1 \mathrm{Rv}$ geeft partijen in de procedure een beginselrecht op het horen van getuigen als zij daarom vragen. Daarmee neemt het getuigenbewijs een bijzondere positie in het bewijsrecht in. Op andere bewijsaanbiedingen mag de rechter ingaan, maar het hoeft niet. Schriftelijk bewijs dient spontaan te worden overgelegd en partijen kunnen ter zake niet een opdracht van de rechter afwachten, de benoeming van een deskundige betreft een rechterlijke discretionaire bevoegdheid, en ook aan een verzoek om de situatie ter plaatse te komen bekijken behoeft de rechter geen gehoor te geven. Daarmee bestaat er tijdens de procedure dus een principieel verschil tussen het aanbod tot het horen van getuigen en het aanbod tot het leveren van ander bewijs dan getuigenbewijs.

Met het voorgestelde art. 166 lid 1 Rv-nieuw wordt dit anders. Volgens het voorstel $k a n$ de rechter op verzoek van een partij een getuigenverhoor toestaan of bevelen. De huidige beginselverplichting tot het horen van getuigen indien partijen daarom vragen, gaat - als het aan de minister ligt dus verdwijnen. Of tijdens de procedure nog getuigen worden gehoord, wordt overgelaten aan de discretionaire bevoegdheid van de rechter. Dit voorstel verdraagt zich moeizaam met de uitgangspunten van (en constateringen in) het advies van de expertgroep waarop het wetsvoorstel is gebaseerd. Ik zal uitleggen waarom ik dat vind.

De expertgroep heeft er terecht op gewezen dat de rechter in de praktijk slechts in beperkte mate ambtshalve aan waar-

\footnotetext{
Mr. F.J.P. Lock is senior-raadsheer in het Gerechtshof Arnhem-Leeuwarden, onderzoeker aan de Radboud Universiteit Nijmegen en lid van de redactie van dit tijdschrift

1. De internetconsultatietermijn is inmiddels gesloten.

2. A. Hammerstein, R.H. de Bock \& W.D.H. Asser, Modernisering burgerlijk bewijsrecht, Den Haag: Boom juridisch 2017.

3. Zie hierover eerder in dit tijdschrift ook het verslag van de aan het advies van de expertgroep gewijde vergadering van de Nederlandse Vereniging voor Procesrecht in het najaar van 2017, 'Hoe zou u het bewijsrecht willen moderniseren?', TCR 2018, afl. 2, p. $42-52$ en R.R. Verkerk, 'De modernisering van het getuigenverhoor', TCR 2018, afl. 3, p. 71-78.
}

heidsvinding via bewijslevering doet. Dat is ook mijn ervaring. Omdat er ook nog eens sprake is van grote verschillen tussen rechters, leidt dit tot onzekerheid bij partijen. Omdat de rechter niet zo snel geneigd lijkt te zijn om tot getuigenverhoren of benoemingen van deskundigen over te gaan, wordt de waarheidsvinding nogal eens tekortgedaan. En dat terwijl waarheidsvinding als een (grond)beginsel van ons burgerlijk procesrecht door de experts juist prominent voorop wordt gesteld: het uiteindelijke doel van het bewijsrecht is mogelijk te maken dat de rechter op basis van een zo volledig en correct mogelijk vastgesteld feitencomplex een juiste en rechtvaardige beslissing neemt.

Het stimuleren van het zo vroeg (al bij aanvang van de procedure) en zo volledig mogelijk aanleveren van bewijsmateriaal door partijen wordt door de expertgroep als een van de belangrijkste verbeteringen van het bewijsrecht beschouwd. Daarom wordt van partijen verlangd dat zij alle relevante informatie over hun geschil zo snel mogelijk op tafel leggen. Als een partij niet beschikt over informatie die wel van belang is, moet zij deze informatie bij de wederpartij of een derde opvragen en daartoe zo nodig bij de rechter om voorlopige bewijsverrichtingen verzoeken. Deze verplichting tot informatiegaring en bewijslevering houdt op waar dat van een partij in een concreet geval niet meer kan worden verlangd. Het gaat om de informatie die een partij redelijkerwijs kan verkrijgen en die redelijkerwijs voorzienbaar van belang is voor de beoordeling van de feiten of rechten waarop deze partij zich beroept ter onderbouwing van haar vordering of verweer, de zogenoemde processuele dubbele redelijkheidstoets.

Deze redenering kan ik volgen. Het lijkt me in het overgrote deel van de zaken niet te veel gevraagd dat partijen die een oplossing zoeken voor hun geschil, alle informatie die daarvoor relevant is op voorhand verzamelen en presenteren aan degene die zij om die oplossing vragen, voor zover dat redelijkerwijs mogelijk is. Het logische gevolg van de verplichting om zo veel mogelijk voorafgaande aan de procedure informatie te verzamelen, is dat in de procedure die mogelijkheden beperkt zijn. Indien partijen niet of niet voldoende gebruik hebben gemaakt van de mogelijkheden van bewijslevering die redelijkerwijs voorhanden lagen, zouden er in de procedure in beginsel geen of slechts beperkte mogelijkheden moeten zijn voor nadere bewijsverrichtingen. Anders is de verplichting tandeloos.

Maar dit heeft ook een keerzijde. Het is goed voorstelbaar dat partijen alles hebben gedaan wat redelijkerwijs van hen 
verwacht mocht worden, en dat in de procedure blijkt dat er toch nog feiten verzameld of gestaafd moet worden waarop de partij niet bedacht behoefde te zijn of waarop zij niet eerder de hand heeft kunnen leggen. Dat kan gelden voor eiser (die bijvoorbeeld wordt geconfronteerd met onverwachte verweren, een reconventionele vordering of een tussenkomende partij), maar misschien nog wel meer voor verweerder, die doorgaans minder tijd en gelegenheid zal hebben om het verweer voor te bereiden dan dat eiser had om de vordering te onderbouwen en die bijvoorbeeld bij wege van verweer een beroep op verrekening met een tegenvordering wil doen of een reconventionele vordering wil instellen. Voorlopige bewijsverrichtingen zijn dan, onder het nieuwe bewijsrecht, niet meer mogelijk.

In dat geval zou, met het oog op het belang van waarheidsvinding, alsnog het recht op bewijslevering tijdens de procedure moeten bestaan. Waarheidsvinding is niet alleen iets voor partijen. De actieve moderne rechter heeft in zijn of haar zoektocht naar de waarheid niet alleen bevoegdheden, maar ook verplichtingen. Natuurlijk ligt de verantwoordelijkheid voor het verzamelen van feiten en het onderbouwen van stellingen primair bij partijen. En aan het verzoek tot (nadere) bewijslevering mag best wel de eis worden gesteld dat wordt uitgelegd waarom dit bewijs niet eerder is verzameld en waarom deze nadere bewijslevering van belang is voor de beslissing van de zaak. Maar als een partij haar preprocessuele verantwoordelijkheid heeft ingevuld en haar verzoek toereikend heeft gemotiveerd, heeft zij er recht op om nader bewijs te kunnen leveren. Zonder dat recht op bewijslevering bestaat het risico dat de zaak buiten redelijkerwijs toerekenbaar toedoen of nalaten van partijen niet voldoende uit de verf komt en dat daardoor geen recht wordt gedaan aan de werkelijke materieelrechtelijke rechtspositie van partijen.

De opmerking in de toelichting bij de voorgestelde wijziging van art. 166 lid $1 \mathrm{Rv}$, dat uitdrukkelijk niet wordt beoogd het horen van getuigen verder (sic!) uit procedures te bannen of de rechter de vrijheid te geven om op de uitkomst van de bewijslevering vooruit te lopen, stelt mij niet gerust. Rechters maken zelden gebruik van de ook nu al bestaande mogelijkheid om ambtshalve getuigenbewijs op te dragen. En alleen al gemeten naar het aantal zaken in cassatie waarin over het passeren van een getuigenbewijsaanbod wordt geklaagd, bestaat er kennelijk bij veel rechters een moeilijk uit te roeien neiging om aan het horen van getuigen te proberen te ontkomen. Of de productiedruk daaraan mede debet is, is moeilijk te meten, maar het is zeker niet uit te sluiten. Met een uitsluitend discretionaire bevoegdheid om getuigen te horen, zal dit niet verbeteren. Dat lijkt me in strijd met de uitgangspunten van het wetsvoorstel en met het (grond)beginsel van waarheidsvinding.

En, daarmee kom ik op mijn laatste punt, dat recht op bewijs zou dan niet alleen voor getuigenbewijs moeten gelden, maar voor alle bewijsmiddelen. Een bijzondere positie voor getuigenbewijs is niet meer van deze tijd. Terecht heeft de expertgroep geconcludeerd dat niet te rechtvaardigen is dat voor het verkrijgen van toegang tot informatie verschillende criteria bestaan, al naar gelang sprake is van mondelinge dan wel schriftelijke informatie. Ook in de toelichting op het wetsvoorstel wordt geconstateerd dat dit de toepasbaarheid of toelaatbaarheid van de verschillende bewijsmiddelen verwarrend maakt en ertoe leidt dat niet altijd op de meest effectieve wijze naar relevante informatie wordt gezocht. Het uitgangspunt dient daarom te zijn dat de criteria voor de toepassing of toelaatbaarheid van alle bewijsmiddelen zo veel mogelijk gelijk zijn. Daarmee zou de beoordeling van het bewijsaanbod ín de procedure in gelijke pas lopen met de voorgestelde harmonisering van de beoordeling van verzoeken tot voorlopige bewijsverrichtingen voorafgaande aan de procedure, namelijk volgens zo veel mogelijk gelijke criteria voor alle soorten bewijsmiddelen.

De paragraaf 'Algemene bepalingen van bewijsrecht' verdient daarom een bepaling waarin aan partijen, indien zij dat voldoende concreet en specifiek verzoeken en indien zij aan de processuele dubbele redelijkheidstoets hebben voldaan, niet alleen voorafgaande aan, maar onder omstandigheden ook tijdens de procedure het recht wordt gegeven op bewijslevering. Dat dit een stortvloed aan overbodige bewijsverrichtingen gaat opleveren, geloof ik niet. Daarvoor vormen de eis dat een partij volgens de processuele dubbele redelijkheidstoets al zo veel mogelijk voorafgaande aan de procedure alle relevante informatie en bewijs moet verzamelen en de eis dat een partij voldoende duidelijk moet maken waarom nadere bewijslevering voor een beslissing van de zaak nodig is, een voldoende hoge drempel. Dat dit zal bijdragen aan de waarheidsvinding en aan het daarmee samenhangende vertrouwen van partijen dat de rechter hun in alle redelijkheid de gelegenheid geeft om de feiten zo correct mogelijk te laten vaststellen, geloof ik wel. Modern civiel bewijsrecht zonder ook een vorm van recht op bewijs in de procedure kan ik mij maar moeilijk voorstellen. 